\title{
A Review on Child Labour Criticism in Bangladesh: An Analysis
}

\author{
Md. Kamruzzaman ${ }^{1,2,3,{ }^{*} \text {, Md. Abdul Hakim }}{ }^{4}$ \\ ${ }^{1}$ Department of Criminology and Police Science, Mawlana Bhashani Science and Technology University, Tangail, Bangladesh \\ ${ }^{2}$ Department of Victimology and Restorative Justice, Institute of Social Welfare and Research, University of Dhaka, Dhaka, Bangladesh \\ ${ }^{3}$ Department of Law, IslamicUniversity, Kushtia, Bangladesh \\ ${ }^{4}$ Department of Food Technology and Nutritional Science, Mawlana Bhashani Science and Technology University, Tangail, Bangladesh
}

Emailaddress

shohag.mbstu.cps@gmail.com (Md. Kamruzzaman), info.hakim.bd@gmail.com (Md. A. Hakim)

\section{To cite this article:}

Md. Kamruzzaman, Md. Abdul Hakim. A Review on Child Labour Criticism in Bangladesh: An Analysis. International Journal of Sports Science and Physical Education. Vol. 3, No. 1, 2018, pp. 1-8. doi: 10.11648/j.ijsspe.20180301.11

Received: October 24, 2017; Accepted: November 3, 2017; Published: February 9, 2018

\begin{abstract}
Child labor is a common practice in developing countries. Child labor is defined as work that deprives children of their childhood, their potential and dignity as an emerging social threat increasing at an alarming rate. The statistical secondary data analysis method was used in this study to estimate the causes and different types of victimization trend on child at workplace in Bangladesh. The authors have experienced that the child are now working in multidimensional sectors like agriculture, service sector, industry, construction, domestic work, transport etc for their hand to mouth. They are forced to perform more than one shift duty a day keeping contradiction with the ILO regulations in this connection. They are on the different kinds of workplace victimization where physical abuse, health injury, economical exploitation and sexual abuse are on the top rank. There is no headache on their educational deprivation in our ongoing society.
\end{abstract}

Keywords: Child Labor, Workplace Violence, Secondary Data, Criticism, Review Study, Bangladesh

\section{Introduction}

The WHO defines child victimization as all forms of physical and emotional ill treatment, sexual abuse, neglect or negligent treatment or commercial or other exploitation, resulting in actual or potential harm to the child's health, survival, development or dignity in the context of a relationship of responsibility, trust or power [1-3, 27, 28]. Workplace victimization can be many types such as physical, psychological, emotional, financial deprivation, health injury, educational deprivation etc when children are forced to work; they are also exposed to situations that make them vulnerable to trafficking, abuse, violence and exploitation. Children work in both formal and informal sectors. Almost $93.3 \%$ of working children are engaged in the informal sector. Most children work in informal sector like agricultural activities include poultry farming, drying fish, salt mining, shrimp farming, and produce logistic. In the workplace they often subjected to harassment, emotional, physical, and sexual abuse. The RMG is the largest employer of child in the formal sector. Girls are mainly involved in garments sector. In those working sector girls are frequently victimized by their co-worker [4-6].

Kamruzzaman (2015) has done a statistical analysis on nature of victimization of child labor at workplace in Bangladesh. He showed that beating (13 percent) and puling hair ( 7.5 percent) is common physical assault for child worker and rape (14.1 percent), sexual perversion (16.5 percent), sexual harassment is common for most sexual abuse. There were 42.4 percent children working at 5-8 hours duration and 30 percent child are in say above 8 hours found in this study $[1,7,29]$.

Rahman and Hakim (2016) worked on the nutritional status of child worker in Bangladesh. They conducted a cross sectional study and the result of the study was of $45 \%$ children were fixed salary earners and $89 \%$ of the workers worked to support their family. Anthropometric assessment showed that their 26 percent respondent were stunned, 15 percent and 26 percent respondents were wasted and gone underweight. Also 39 percent of the children were thinner. Overall, 52.1 percent and 60.8 percent of the calorie are 
needed to the boy and girl child workers and 77.6 percent and 82.2 percent of the protein requirement were fulfilled by boys and girls respectively except thiamin and vitamin $\mathrm{C}$ other micronutrients were very poorly fulfilled [8].

Hakim and Talukder (2016) presented an overview of children condition in workplace. In his research, he presented those working children particularly those in domestic work are at risk of abuse and exploitation. The fact is that more than half of these domestic workers receive now a days all instead of monetary benefits such as accommodation, food and clothing. Hundreds of thousands of Bangladeshi children work in hazardous jobs. Such hazardous job including: physical, psychological or sexual abuse; excessive work hours; an unhealthy environment and these increase the risks ofd eveloping bronchial complaints, cancers and other form of life threatening diseases [9].

Islam (2010) in their paper give an overview on the situation of child domestic worker in Bangladesh and child specialist's attitude about the child domestic work towards ILO new standards of decent work for domestic workers. This study shows that the education level of those children who work as domestic workers is very poor and the larger portion (79.2 percent) has now al to get non-formal education. They also find that almost all (73.3 percent) did not get any full day off during the week and ( 21.7 percent) workers get rest breaks only for 3-4 hours and the alarming thing is (19.2 percent) children did not get any time to take rest during the day [5].

Rahman and Hakim (2016) examined the effect of child labour on child health outcome in Bangladesh. They have found to have $60.42 \%$ underweight and $6.25 \%$ overweight condition with the ability $63.75 \%$ of them to manage thrice meals a day although their hygiene practices are not in well off status [4].

Rahman et al. (2016) have shown a link on health status and educational background of the child laborours at Dhaka and Chittagong city in Bangladesh. Their analyses revealed that $37.26 \%$ kids were in malnourishment having no link regarding their achieved educational status [6, 10, 30, 31].

Bangladesh Shishu Adhikar Forum (2013) provided a report on domestic child worker. Their main focus was about the situation and problem of domestic worker. This report shows that the child as domestic worker is often the victim so physical, mental and even sexual violence by their employers. It is find out that child domestic worker often victims of torture and sometime victimized by severe torture. It may cause fatal injury to them. It also happened that domestic workers even died because of severe torture and injury $[32,33]$. The report showed that the child workers were tortured for very trivial reasons like not to perform their duty properly, delay in work, or simply breaking a glass. The brutality of torture on the children ranged from beatings, hitting the head on the wall, burning by cigarette or any other metal things, non-payment of salary. The girl children are usually the victims of sexual abuse or rape by the male members of the households. For every child domestic worker verbal, mental, physical or sexual abuse is common problem. For any simple mistake, they are slapped, kicked, punched, pulled by their hair and also addressing rough hand obscene languages $[11,12]$.

\section{Methodology}

This study is a secondary research and secondary data has been used to conduct the study. Secondary data has been collected from different sources like reports of various organization, various books, journals, news paper and articles. Also vast data have been collected from various web links. All those data are analyzed in different way for finding different relevant thing son child victimization at workplaces in Bangladesh.

\section{Results}

Based on secondary data related to workplace child victimization following findings are found.

\subsection{Child and Child Labor}

The children Act, 2013 define child as any person under 18 years old (Section 4). The 1999 International Labor Organization Convention on the Worst Forms of Child Labor defines a child as an individual under the age of 18 years.

According to the UNICEF, the United Nations Children's Fund, defines child labor as work that exceeds a minimum number of hours, depending on the age of a child and on the type of work. For children aged 5 to 11 , this would include at least one hour of economic worker 28 hours of domestic work per week. For the 12 to 14 age group, this would include at least 14 hours of economic work or 28 hours of domestic work per week and for children aged 15 to 17 , child labor occurs when a child works at least 43 hours of economic or domestic work per week [13].

According to the ILO asserts that the term child labor refers to work that is mentally, physically, socially or morally dangerous and harmful to children and interferes with their schooling by depriving them of the opportunity to attend school, obliging them to leave school prematurely or requiring them to attempt to combine school attendance with excessively long and heavy work $[14,15]$.

Table 1. Minimum age of children to work。

\begin{tabular}{lll}
\hline General minimum age for admission to employment or work & No general minimum age & \\
\hline Sector & Age & legislation \\
\hline Transport of passengers, goods or mails by train, or handling of & 15 years & Section 3 of the Employment of Children Act \\
Tea plantations & 12 years & Section 23 of the Tea Plantations Labor Or dinanc \\
Mines & 15 years & Section 26 of the Mines Act \\
Factories & 14 years & Section 76 of the Factories Rules \\
\hline
\end{tabular}




\begin{tabular}{|c|c|c|}
\hline General minimum age for admission to employment or work & No general minimum age & \\
\hline Sector & Age & legislation \\
\hline Shops and commercial establishments & 12 years & Section 22 of the Shops and Establishments Act \\
\hline Shops and commercial establishments & 12 years & Section 22 of the Shops and Establishments Act \\
\hline Road transport services & 18 years & Section 3 of the Road Transport Workers Ordinance \\
\hline Admission to light work activities & $\begin{array}{l}\text { No minimum age for admission } \\
\text { to light works pecified }\end{array}$ & \\
\hline $\begin{array}{l}\text { Admission to hazardous work } \\
\text { specified }\end{array}$ & $\begin{array}{l}\text { No general minimum } \\
\text { Age for hazardous work }\end{array}$ & No list of the types of hazardous work determined \\
\hline
\end{tabular}

\subsection{Present Situation of Child Labor}

Bangladesh is a developing country. Gradually it's growing towards the success. But it is a great hindrance to development, as a large portion of children group become engage with working sector without attending the school.
Day by day the number of working children alarmingly increased and they involve in all sorts of work: industrial, agriculture, construction and many hazardous work. Among them large portion of children $(46 \%)$ are engage in agriculture sector, $36 \%$ are in service and $19 \%$ are in industry work both the girls and boys are engage in work.

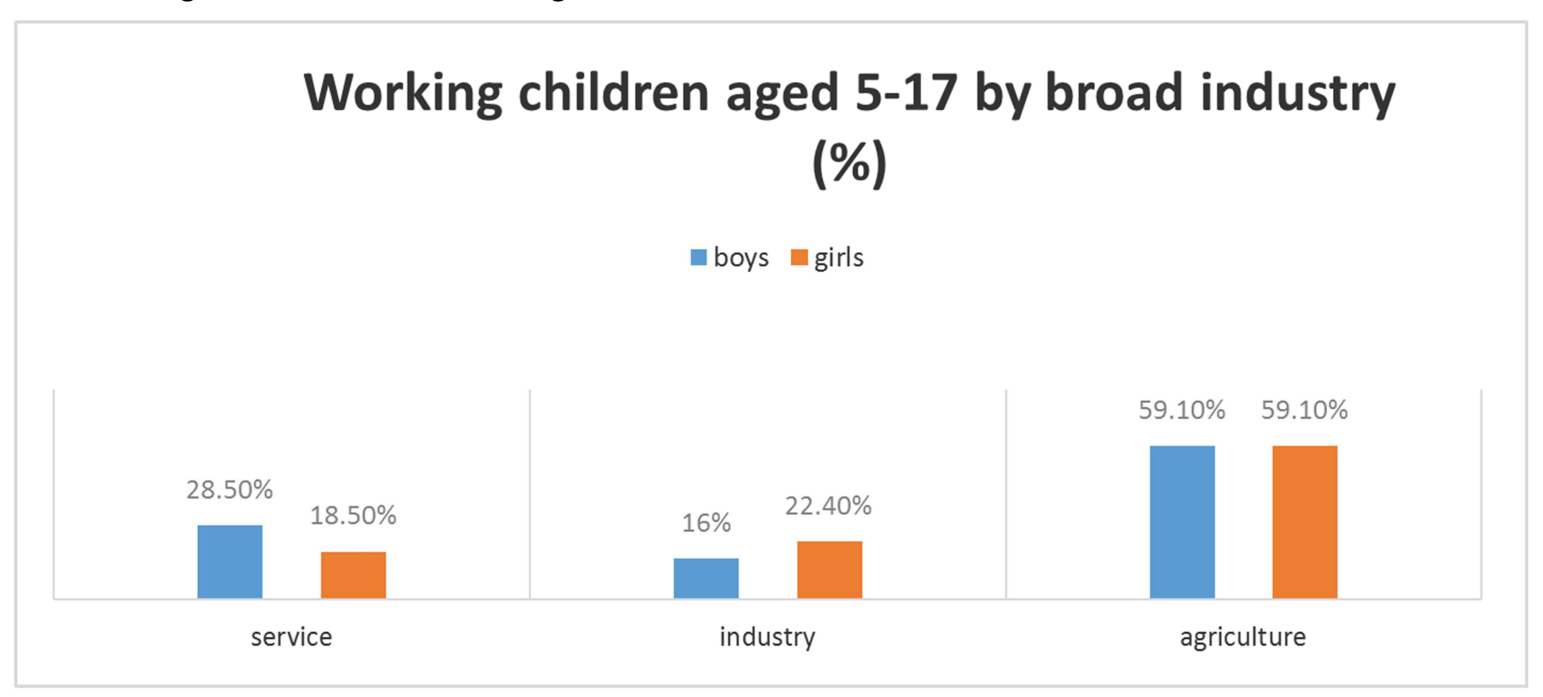

Figure 1. Distribution of working children by age and sex.

According to the figure 1, we have found a comparison between boys and girls (5-17 year) in the working sector. Among the three sectors in agricultural sector the proportion of boys and girls worker is equal, in service sector girls worker is lower than boys and in industry sector girls worker is higher than boys.

Table 2. Distribution of child labor by how many hours they work each week and age.

\begin{tabular}{|c|c|c|c|c|c|}
\hline \multirow{2}{*}{ Hours work } & \multicolumn{5}{|c|}{ Age group } \\
\hline & 5 & 6-11 & $12-13$ & $14-17$ & total \\
\hline$<12$ & 18.1 & 8.2 & 0.2 & 0.2 & 2.4 \\
\hline $13-42$ & 81.9 & 87.9 & 68.1 & 11.1 & 32.7 \\
\hline$>42$ & 0 & 4.2 & 31.7 & 88.7 & 64.9 \\
\hline
\end{tabular}

(Source: Child labor survey 2013.)

\subsection{Children Victimization in Different Workplaces}

\subsubsection{Domestic Work}

Child Domestic Labor is one of the most common forms of child labor. Traditionally, more girls are employed in domestic service than in any other forms of work. A baseline survey by ILO in 2006 estimates that there are approximately
4,21,000 child domestic workers between the ages of 6-17 year in Bangladesh of which 78 percent are girls. It is alleged that child domestic workers often become victims of torture including severe atrocities that may lead to fatal injury and may even lead to their death.

Table 3. Picture of domestic worker torture.

\begin{tabular}{llll}
\hline Year & Dead & Wounded & Total \\
\hline 2009 & 37 & 34 & 71 \\
2010 & 56 & 30 & 83 \\
2011 & 38 & 20 & 58 \\
\hline
\end{tabular}

(Source: Bangladesh institute of labor studies)

CRC Alternative Report 2013 from Bangladesh highlighted that out of 23 incidents, 22 depicted severe torture on domestic workers. The analysis of the report showed that the child workers were tortured for very inconsequential reasons such as not performing a duty properly, delay in work, or simply breaking a glass. These verity of torture ranged from beatings, slapped, kicked, punched, pulled by their hair or addressed in vulgar and obscene languages, hitting the head on the wall, burning by cigarette or any other metal things, non-payment of salary and rape. 


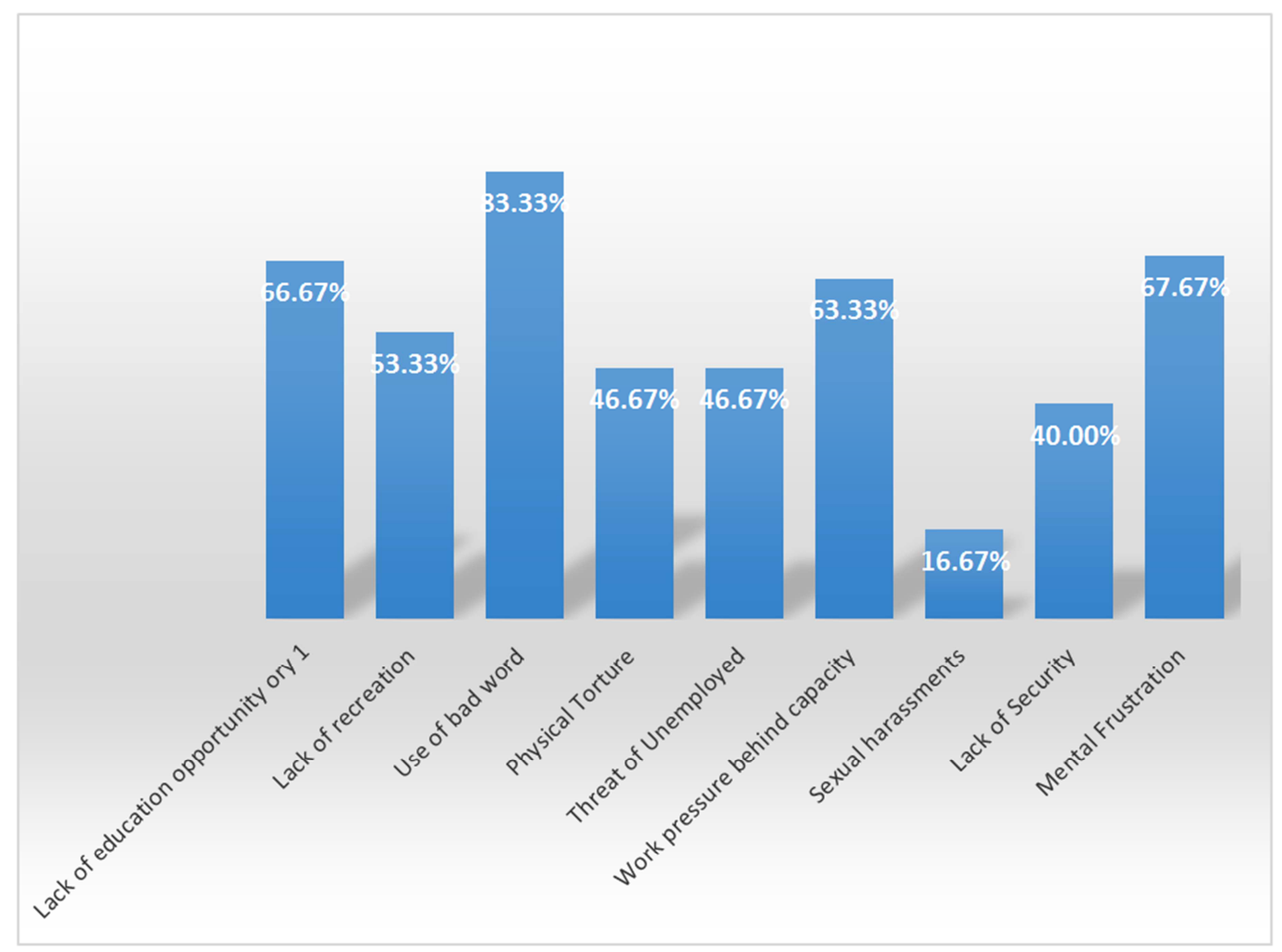

(Source: Bangladesh institute of labor studies)

Figure 2. Nature of victimization in domestic work.

\subsubsection{Working Sectors}

\section{(i) Battery Recharging/Recycling Sector}

A 2003 baseline survey on child labor in the battery recharging or recycling sector estimated that there were some 5,500 children aged 5-17 years working in this sector in over 12,000 establishments throughout Bangladesh, about onequarter of the total sector workforce. The survey found that the children concerned had to work an average of over eight hours per day, for six or seven days per week, in exploitative conditions with extremely limited remuneration. Some 15 percent of the child workers were forced to work exceptionally long hours- 11 or more per day; just eight percent attended school. 13 percent of the children were provided with any form of protective gear, and $23 \%$ contributing to a very high rate of work-related illness an din jury.

\section{(ii) Welding Sector}

A 2003 baseline survey of child labor in welding establishments put total children concerned aged 5-17 year sat 39,000 throughout the country. The survey found that the work was very time intensive children worked on average nine hours per day and that school attendance among the children extremely low (four percent). Welding work was found to be even more hazardous for children. 41 percent reported some form of work-related injury or illness, 93 percent requiring medical attention. Burning was a particularly serious hazard, affecting some 2,272 children. Almost half (45 percent) of the children concerned were deprived of safety gear, including masks for eye protection while welding.

\section{(iii) Road Transport Sector}

A 2003 baseline survey on child labor in the road transport sector estimated that some 85,600 children were engaged in road transport activity across almost 10,000 locations throughout the country. Of the children concerned, one-half were helpers on buses or minibuses, one-third were rickshaw pullers, one-fifth were conductors and the remainder were cleaners or conducted miscellaneous tasks in accordance with the instructions of the driver. Almost half of concerned children worked seven days per week, and children put in an average of almost 10 working hours per day. Almost half of concerned children reported health problems, and 42 percent reported abuse by owners or employers at the workplace. Abuse was typically but not exclusively verbal in nature.

\section{(iv) Automobile Establishment}

A 2003 baseline survey on child labor in automobile establishments put total children concerned aged 5-17 years at 15,900 (all boys), constituting 42 percent of the total sector workforce. The survey found that children worked for an average of over nine hours per day for six or seven days per week. Rate so fill ness and injury to children were very high 
(32 percent), testimony to the adversity of the work environment in auto work shops and to the lack of protective gear. About 28 percent of the children were reportedly abused by their employers, of which about one in ten was physically abused.

\section{(v) Ready-Made Garment Sector}

Bangladesh is considered to have the child labour problem especially in the RMG sector. Nearly all the child labor in export industries is found in the garment sector. It is reported that most of the children are girls with an average age of just over 13 years. Garments owners prefer girls under 15 years because they work for less, and are more likely to be unmarried with no children or domestic responsibilities. According to a statistics published in the Bhorer Kagoj on $12^{\text {th }}$ January, 1992, in different garments factories of Bangladesh $30 \%$ of the workers were children. They did non stop work, were not provided with transportation or food and had no scope to enjoy weekly holiday for medical leave. Another study shows that there is no paid leave for holidays, and salary is deducted if the child is absent, or for unproductive periods due to load shading electricity and temporarily production goes out . Most child workers do not use protective gear and have no concept on occupational health and safety issues. As a result, they are suffering serious injuries and sometimes death in the workplaces.

\section{(vi) Tannery}

According tot he Human Rights Watch report 2013, Workers in many leather tanneries in the Hazaribagh neighborhood of Dhaka, the Bangladesh capital, including children as young as 11 become ill because of exposure to hazardous chemicals and are injured in horrific workplace accidents. A report named "Toxic Tanneries: The Health Repercussions of Bangladesh's Hazaribagh Leather," documents an occupational health and safety crisis among tannery workers, both men and women, including skin diseases and respiratory illnesses caused by exposure to tanning chemicals, and limb amputations caused by accidents in dangerous tannery machinery. Residents of Hazaribagh slums complain of illnesses such as fevers, skin diseases, respiratory problems, and diarrhea, caused by the extreme tannery pollution of air, water, and soil.

\subsection{Type of Victimization}

After reviewing the above described literature and above mentioned data following types of victimization are found among the working children.

\subsubsection{Physical Abuse and Violence}

Working children, particularly those in hidden jobs such as domestic labor, are at risk of abuse and exploitation. Onequarter of all working children reported that they had been physically punished at their workplaces, according to a 2008 children's opinion poll (UNICEF, Opinions of Children of Bangladesh on Corporal Punishment, November 2009).

About 60 percent child domestic worker report some kind of abuse during their work, such as scolding or slapping. Levels of exploitation are also extremely high, as in dicated by the fact that more than half receive now age at all (Baseline Survey on Child Domestic Labor in Bangladesh, 2006).

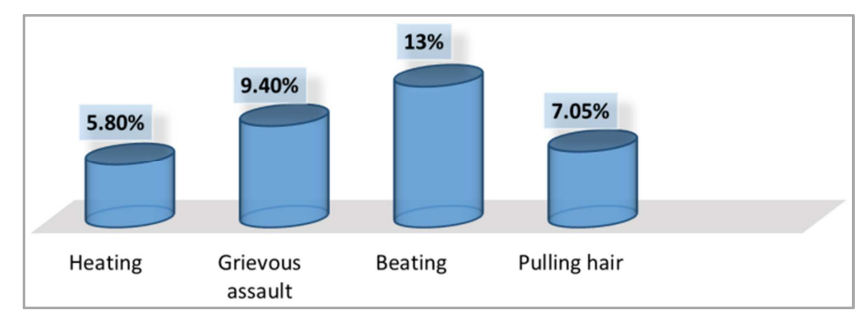

Figure 3. Physical Assault.

This data shows that over all physical victimization among child worker of which beating is the most common nature of physical assault $(13 \%)$. Besides beating children are also victim of grievous shurt, pulling hair.

\subsubsection{Sexual Abuse}

Working children often live away from their families in situations where they are exposed to violence, abuse and economic exploitation. Their vulnerable situation puts them at risk of trafficking as they seek a better life for the mselves. A rapid assessment of commercially sexually exploited children showed that half worked in other sectors before being lured into sex work. Additionally, more than half had been forced or trafficked into the industry, lured by false promise so fjobsor marriage. The life of a child sex worker is one of violence, exploitation and physical and psychological health problems. The majorities are depressed and threequarters of the child sex workers were ill in the three months before the rapid assessment survey, many with sexually transmitted diseases. In the 3-12 months prior to the survey, one-quarter of the children were beaten, and another quarter were raped 14 (UNICEF Bangladesh and INCIDIN, Rapid Assessment: Commercial Sexual Exploitation of Children and Adolescents in Bangladesh, 2008).

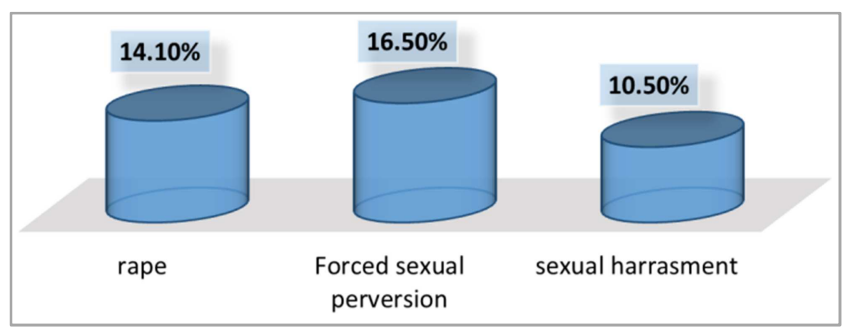

Figure 4. Sexualabuse [1].

\subsubsection{Educational Deprivation}

Educational deprivation is one of the common scenes in child labor. The Child Labor Survey (CLS) found that 36.4 percent of the working children are not going to school at all. Further, Khan (2001)'s study indicated that 38.3 percent of child laborers are not going to school. The present study shows the education level among the child laborers that 40 percent had no formal education. Khan's study found that about 50.7 percent child workers completed between classes one to five. Only 9.3 percent of child workers completed an education of 
class five to ten. In this study, it was found that 40 percent of child workers had no formal education. The school attendance of children in employment agged behind that of their nonworking counterparts at every age in Bangladesh. Children's employment appears to interfere strongly with their ability to attend school in Bangladesh. There was a five percentage point attendance gap between children in and notinemploy mentatage seven years, rising to 27 percent age point satage 14 years. Not surprisingly, attendance was negatively correlated notonly with involvement in work but also with the time children spend actually working.

\subsubsection{Health Injury}

Children engaged in work are exposed to a variety of hazards workplace like dangerous machinery, falling objects, pesticides, chemicals, and abusive employers that have the potential to seriously damage their health [34]. The specialized baseline surveys provide some idea of the immediate health consequences associated with children's employment in specific sectors. The 2003 baseline survey on child labor in the battery recharging or recycling sector indicated that 13 percent of the children were provided with any form of protective gear, 23 percent contributing to a very high rate of work-related illness and injury [16-19, 35, 36]. The 2003 baseline survey of child labor in welding establishments by ILO indicated that welding work, hazardous even for adult workers, was even more so for children 41 percent reported some form of workrelated injury or illness, and 93 percent requiring medical attention. Almost half of children concerned reported health problems in the 2003 baseline survey on child labor in the road transport. Children experienced work-related ill-health found in the 2003 baseline survey on child labor in automobile establishments. The 2006 baseline survey of child domestic labor indicated that 60 percent suffered some form of abuse which causes them fatal injury.

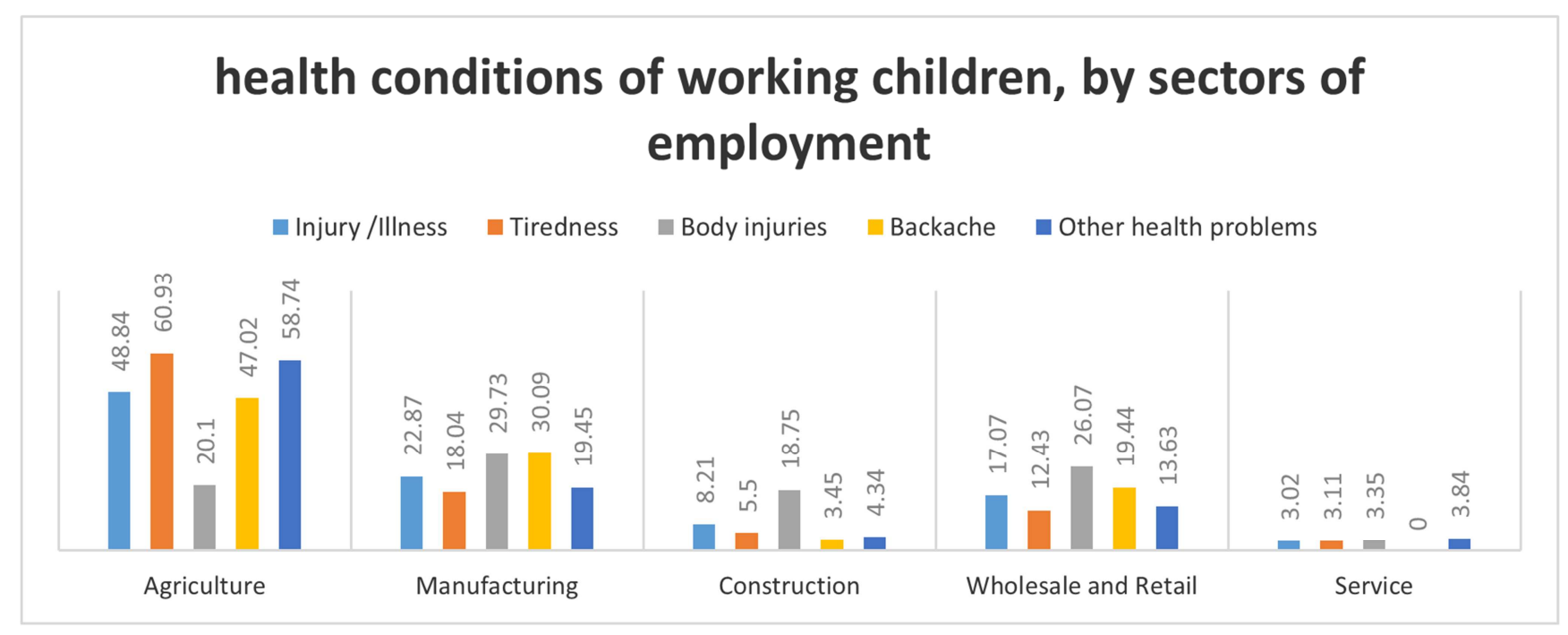

(Source: Data are from NCLS -2002.)

Figure 5. Health condition and working sector.

\subsubsection{Economical Exploitation}

Wages serveas the main incentive for child labor. Wages may be paid on daily, weekly, or monthly basis. $79 \%$ children work on monthly contract basis, $3 \%$ work for only meal and accommodation. A sign if I can't number of child workers (17 percent) are doing domestic work merely on false hopes, which includes providing better job facilities for their family members, possibility of higher wages in future. Nearly 80 percent to fc hild domestic laborers get Tk.300-1200 per month (approx. USD3-12). This amount looks very pitiable compared to the value of money. Around $27 \%$ of the $\mathrm{m}$ get only Tk.300-600 per month. They are possibly the lowest wage earners in the Country. In ship braking sector child workers got 50-60 taka per day for their efforts (ILO, A baseline survey on child labor, 2003). Another study shows that 50.2 percent out of the total child workers had a monthly income of less than Tk.600 (7.50 USD). In addition, the highest percent $(27.6 \%)$ of child workers had monthly income of between Tk. 301-600 and 13.3 percent had monthly income of between Tk.601-900. In the study, it was found that less than one percent $(0.9 \%)$ of child workers had incomes of more than Tk. 2,101 (26.3USD). With this amoun to wages child workers have difficulties to meet minimum basic needs such as nutritious food and health care services. Most of the child workers engaged in overtime work in order to earn extra money but they did not get extra money in mostly cases. The study of Rashid and Prodhan (2013) revealed that $46.7 \%$ of the child workers did not receive a bonus on special occasion so holidays while 33.3 percent of the child laborers did receive a bonus on religious festivals such as Eid or Puja. Half of the child workers did not get extra money for overtime work, while 33.3 percent did receive a small amout of extra money.

\section{Case Studies}

In very recent year incident of child victimization in 
working place frequently published in daily newspaper. It's become a burning issue. Some of incident present below:

\subsection{Case-1}

Child Rakib, a 12 years old boy was a worker in a garage. Because of their poor family situation hedrop soutthe school and joins as worker in a garage. Rakib with his mother and his younger sister Rini (9) lived in a house in Tutpara, Central Road, Khulna. Though he works hard but owner did not pay him duly. For any simple mistake he had to suffer the torture. He couldn't tolerate such torture and decided to work other garage. Shorif, the owner of the garage was so much angry on this and make a plan with his cooperator to kill Rakib. August, 3, 2015, Shorif called Rakib to his garage and revile him. One of the other workers of garage holds Rakib and laid down him and grasps a compressor pipe on his rectum and supply the air. Rakib's abdomen began to gummy. He constantly shouted to release him. Local people come and take Rakib to the nearby clinicbu this condition was so serious so that the doctor referred to the Khulna hospital. But he died on the way. Doctor said that because of pumping so much air his guts and lung was dissipate [20-22].

\subsection{Case-2}

Shagor Barmon, a nine years old boy was work in Jobeda Textile Mill at Rupganj, Narayanganj. Factory manager (administration) Nazmul Huda, production manager HarunurRashaid and with other line man killed Shagor in the factory in 24 July 2016. His father gives the statement that the manager almost regularly uses bad language to Shagor. Sometimes Shagor protests against such behavior. For reason the manager killed him [23-26, 37].

\section{Conclusions}

Children are the future of a nation and so if they are exploited, they would not be able to contribute in the country's welfare. Moreover, children consistently expressed their concerns about the absence of a safe environment which leads them to violence, abuse and exploitation within the family, community, street, workplace and school. They are victimized randomly in their workplaces across the country. Hitting, punching, burning, killing and rape are happening against them. They also suffer from health injury due to working at their premature stage. These working children are highly deprived of the education. It can make a great impact at all parts in the society. This is why they are in need of proper action at the national level to take care them for their flourish growing as they can be the asset of nation in future.

\section{Recommendations}

Child labor is a long-term developed problem that will not be resolved with short-term initiatives. A great deal of work remains to be done to respond in an effective manner to the child labor problem. We can take the following necessary steps shortly with a view to resolve these ongoing problems.

a) An information collecting centers hould be established.

b) Developing public and political awareness.

c) Arranging social and legal support to th evictims.

d) Including information on child rights to NCTB curriculum.

e) Increasing social security.

f) Reformation of law and implement strictly.

g) Regular monitoring of child labor and rights situation of disabled children.

h) Introducing NGO levels chool for them.

i) Developing social services including their basic rights.

j) Mass awareness to adopt the ILO laws for the job givers.

\section{References}

[1] Kamruzzaman M. Child victimization at working places in Bangladesh. Am J Appl Psychology 2015; 4(6): 146-49.

[2] www.who.int.

[3] Zaman S, Matin S, Kibria G. A study on present scenario of child labour in Bangladesh. IOSRJ Business Management 2014;16(6):25-36.

[4] Hakim MA and Rahman A. Health and nutritional condition of street children of Dhaka city: an empirical study in Bangladesh. Sci J Public Health 2016;4(1-1):5-9.

[5] Islam MR. The situation of domestic child workers in Dhaka city. In Shishu Odhikar Forum, Dhaka 2010.

[6] Rahman A, Hakim MA Hanif MA, Islam MR and Kamruzzaman M. Dietary practices, health status and hygiene observance of slum kids: a pilot study in an Asian developing country. JP J Biostat 2016;13(2):195-205.

[7] Hakim MA and Kamruzzaman M. Nutritional status of central Bangladesh street children. Am J Food Sci Nutr Res 2015;2(5):133-37.

[8] Rahman A. and Hakim MA. Anepidemiological study on hygiene practice and malnutrition prevalence of beggars children in Bangladesh. Int J Nutr Diet 2016;4(1):29-46.

[9] Hakim MA and Talukder MJ. Anassessment of health status of street children in Tangail, Bangladesh. Sci J Public Health 2016;4(1-1):1-5.

[10] Kamruzzaman M, Hakim MA, Hanif MA, Rahman MH, Islam MA, Talukder MJ and Islam MR. Patterns of behavioral changes among adolescent smokers: an empirical study. Front Biomed Sci 2016;1(1):1-6.

[11] Kamruzzaman M and Hakim MA. Livelihood status of fishing community of Dhaleswari river in central Bangladesh. Int $J$ Bioinformatics Biomed Eng 2016;2(1):25-29.

[12] Kamruzzaman M and Hakim MA. Factors associated with the suicidal Tsunami as a mental illness: findings from an epidemiological study. Am J Env Sust Dev 2016;1(1):1-5.

[13] ILO. Baseline survey on child domestic labor in Bangladesh 2006. 
[14] Hakim MA and Kamruzzaman M. Nutritional status of central Bangladesh street children. Am J Food Sci Nutr Res 2015; 2(5):133-37.

[15] Islam MS, Hakim MA, Kamruzzaman M, Safeuzzaman, Haque MS and AlamMK. Socioeconomic profile and health status of rickshaw pullers in rural Bangladesh. Am J Food Sci Health 2016; 2(4):32-38.

[16] Kamruzzaman M and Hakim MA. Basic rights on the wane, human rights on brown study: a case study on thrown away children in Bangladesh. Int J Env Plan Manage 2016; 2(4):2935 .

[17] Badr TA. Exploitation of Child Domestic Workers in Bangladesh. Avon global center for women and justice 2010.

[18] Kamruzzaman $M$ and Hakim MA. Social, biology and economic life of children links on street-begging in Bangladesh:across-cultural multivariate analysis. Math Letters 2017; 3(1): 12-19.

[19] Kamruzzaman M and Hakim MA. Socio-economic status of slum dwellers: an empirical study on the capital city of Bangladesh. Am J Business Society 2016, 1(2):13-18.

[20] The Daily Prothom Alo, July 26, 2016.

[21] Kamruzzaman M and Hakim MA. Prevalence of acid crime victimization in South Asia:a review. J Biol Env Eng 2016;1(2):17-22.

[22] Kamruzzaman $M$ and Hakim MA. Food and nutrition counseling in Bangladesh:a NC4HD approach in health statistics. Am J Biol Chem 2016; 5(1):1-5.

[23] The Daily Prothom Alo, August 5, 2015.

[24] Hakim MA and Kamruzzaman M. The dance of poverty and education for childhood nutritional victimization in Bangladesh. J Bio lEnv Eng 2016;1(1): 6-9.

[25] Hakim MA. Malnutrition prevalence and nutrition counseling in developing countries: a case study. Int J Nurs Health Sci 2016; 3(3):19-22.
[26] Megabiau B and Rahman A. Prevalence and determinants of chronic malnutrition among under-5 children in Ethiopia. Int J Child Health Nutr 2013;2(3): 230-23.

[27] Rahman A and Hakim MA. Modeling health status using the logarithmic biophysical modulator. J Public Health Epidemiol 2017; 9(5):145-150.

[28] Hakim MA. Biophysical modeling of dietary energy in biochemical modeling. Eur J Biophys 2017; 5(3):57-81.

[29] Hakim MA. Modeling food energy in bioenergetics. $J A d v$ Med Pharm Sci 2017;14(4):1-7.

[30] Hakim MA. Simulating the ideal body weight in human populations. Int J Biochem Biophys 2017;5(4):79-82.

[31] Linkon KMMR, Prodhan UP, Hakim MA and Alim MA. Study on the physicochemical and antioxidan properties of nigella honey. Int J Nutr Food Sci 2015;4(2):137-140.

[32] Hakim MA. Mathematical modeling of energy balancing for diet planning in nutritional physics. Int J Nutr Diet 2017; $5(1): 29-41$.

[33] Kamruzzaman M, Islam MA, Islam MS, Hossain MS and Hakim MA. Plight of youth perception on cyber crime in South Asia. Am J Information Sci Comput Eng 2016; 2(4):2228.

[34] Hakim MA. Trick to get rid of formalin. The Daily Star 2015. Available at http://www.thedailystar.net/trick-to-get-rid-offormalin-58341 (Accessed on January 04, 2015).

[35] Hakim MA and Islam MS. Elementary of Food Science and Technology ( $1^{\text {st }}$ edn), 2016. Gyankosh Publication, 38 Banglabazar, Dhaka, Bangladesh [ISBN984-658-612-6], p.3540 .

[36] Hakim MA. Simulating ideal body mass in adult human samples. Int J Sport Sci Phys Educ 2017;

[37] Rahman A. Estimating small area health related characteristics of populations: a methodological review. Geospat Health 2017; 12(1): 3-14. 